\title{
Renewable Energy Use, Real GDP, and Human Development Index in Bangladesh: Evidence from Simultaneous Equation Model
}

\author{
Rabeya Basri ${ }^{1}$, Jannatul Ferdous ${ }^{2}$, Md. Ramzan Ali $^{3}$ \\ ${ }^{1}$ Assistant Professor, Department of Economics University of Rajshahi, Rajshahi-6205, Bangladesh \\ ${ }^{2}$ MSS, Department of Economics, University of Rajshahi, Rajshahi-6205, Bangladesh \\ ${ }^{3}$ Senior Officer and Manager Operation, Union Bank Limited, Rangpur Branch, Rangpur, Bangladesh
}

\begin{tabular}{|c|c|}
\hline ARTICLE INFO & ABSTRACT \\
\hline $\begin{array}{l}\text { Publication Online: } \\
12 \text { April } 2021\end{array}$ & $\begin{array}{l}\text { This paper tries to seek out the correlation between renewable energy use, real GDP, and HDI in } \\
\text { addition to trade openness, urbanization, and environmental aspects in the case of Bangladesh during } \\
\text { the phase of 1990-2015. In persuasion of the objective, time-series data of the given period is analyzed } \\
\text { by means of the 2SLS approach. We also apply the VECM Granger causality technique in order to } \\
\text { find the underlying relationship between the given variables. Findings of the study suggest that real } \\
\text { GDP, } \mathrm{CO}_{2} \text { emissions, and use of renewable energy have positive consequences on the human } \\
\text { development index while trade liberalization and urbanization have insignificant impacts on it. The }\end{array}$ \\
\hline Corresponding Author: & study finds renewable energy use improves human development processes. Therefore, the government \\
\hline Rabeya Basri & should emphasize on renewable energy production and the use of renewable energy. \\
\hline
\end{tabular}

\section{INTRODUCTION}

Adequate energy is the prerequisite of economic development through which social welfare takes place (Wang et al., 2018). In order to attain sustainable development, energy plays a crucial role as a factor of production (Ellabban et al., 2014; Koçak \& Şarkgüneşi, 2017). It is the key to sharpening competitiveness in the market as it acts as a cost element. Therefore, energy is important for both producers and consumers. Producers consider energy as a key input for these products, where consumers treat energy as a major portion of household expenses that determines their standard of living (Fotourehchi, Z., 2017).

Energy can be used as a major tool to eliminate poverty and boost human development bringing in economic development (Karekezi et al., 2012). Historically, industrialization and economic development thrived by extensive use of energy (Warr and Ayres, 2010). A number of researchers have revealed a positive association between energy use and economic growth (Sadorsky, 2009; Chang et al., 2015; Inglesi-Lotz, 2016; Bhattacharya et al., 2016; Fotourehchi, 2017; Soava et al., 2018). Energy contributes significantly to advancing the economy of any nation. Energy influences human welfare and economic growth as a whole. For instance, the availability of energy services smoothens the progress of modern health facilities, education, and communication, and vice versa (Ouedraogo, 2013). Also, electricity is the primary requirement of enjoying superior living well-equipped with modern amenities. Incomegenerating activities, modern communication, smooth and fast flow of information, education, and improved health service; all these primary requirements of human development are backed by availability and affordability of adequate levels of electricity. (Raheem et al., 2016). However, in the course of bringing economic development, energy consumption accelerates climate change that can be checked through the use of the renewable form of energy. Economic growth is backed by sufficient levels of production of goods and services where energy acts as an important driving force. Moreover, the use of energy extracted from only renewable sources may assure sustainable economic growth. Therefore, the developed countries transform their use of energy from traditional sources to renewable energy sources to tackle the future concerns of energy (Wang et al., 2018).

The main drawback of fossil-based energy is that it triggers massive damage to nature whereas renewable energy resources repetitively replenish themselves exposing less or no harm to the environment. Thus, renewable energy helps in preserving the environment in the long run (AhAtil et al., 2019). Recognizing the ability of renewable energy to reduce carbon dioxide emissions, renewable energy is preferred to nonrenewable fossil-based energy sources (Dogan and Seker, 


\section{Equation Model"}

2016). Today, priority is given to renewable energy as it is one of the most sustainable and viable solutions to energyrelated environmental issues. Consequently, the expansion of renewable energy will further sustainable development (Dincer, 2000; Kazar and Kazar, 2014). Investment made on renewable energy assists in economic development resulting in constructive externality by increasing local production and creating more employment as well as reducing import payments (Can and Corkmaz, 2018). Thus, renewable energy use reduces carbon emissions that subsequently helps in increasing economic growth. Economic growth furthers economic and social development which contributes to the fulfillment of basic needs of the people resulting in uplifting the level of human development. Considering the importance of the relationships between the variables, the study tries to examine the association between renewable energy use, real GDP, and human development index including $\mathrm{CO}_{2}$ emissions, trade liberalization, and urbanization in the case of Bangladesh.

Selecting Bangladesh as the case study has several convincing reasons. Statistical data shows that Bangladesh was $135^{\text {th }}$ of the $189^{\text {th }}$ nations and territories in 2018 in terms of HDI. HDI value of Bangladesh was 0.614 in 2018 which is considered to be less than the average 0.634 for medium human development country groups (UNDP, 2019). Thus, Bangladesh belongs to the low human development category in terms of HDI. Moreover, $41.7 \%$ of people of Bangladesh are regarded as multidimensionally poor, whereas another $21.4 \%$ are categorized as exposed to poverty. In view of the Gender Inequality Index (GII) of Bangladesh, the indicators are not pleasing $(0.536)$; Bangladesh holds $129^{\text {th }}$ position out of 162 countries in the 2018 index. Furthermore, the economy of Bangladesh is constantly fighting against natural calamities like devastating floods, extreme drought, and destructing cyclones which bring massive sabotage to the infrastructure every year. Data shows that Bangladesh is terribly exposed to the effect of climate change as it belongs to among 10 top most environmentally vulnerable countries of the globe. In order to replenish the damages caused by natural catastrophes, a large portion of the GDP is drained away creating an impediment to the well-being of the community and worsening the condition of disadvantaged people. On the other hand, the energy demand of the country is at a constant rise. Every year an approximately 500megawatt electricity pressure is rising gradually owing to an increasing population, the development of industry, enormous dependency on motor transportation, and so on. Therefore, we incorporate the given variables to analyze their relationship in the case of Bangladesh.

Our study adds value to the existing literature from different directions. First, the study includes a new group of variables, which are human development index, real GDP per capita, renewable energy use, carbon dioxide emissions, trade openness, and urbanization. To the best of our knowledge, no article studied this set of variables from the perspective of Bangladesh. Second, this research is the foremost endeavor to examine the association between renewable energy use, real GDP, and HDI in Bangladesh particular situation in clarifying the HD process. The prevailing energy shortage of the country is distressing every single segment of the economy as well as human life. Approximately $24 \%$ of the total population is deprived of electricity supply in 2016 resulting in a poor standard of living. Bangladesh is a country of opportunity filled with ample natural resources and the possibility for renewable energy to thrive. Though the energy and HD process in Bangladesh is at rise, it is not sufficient enough for sustainable development. This study would provide a new understanding to the policy makers to comprehend the importance of renewable energy use in the process of HD of Bangladesh. Finally, the existing literature did not apply two stages least square (2SLS) method to investigate the connection between the analyzed variables in the case of Bangladesh. We apply the 2SLS method to examine the time series data of Bangladesh. Before applying the 2SLS method, we verify the unit root test of the data and run regression model. Finally, we use the Granger causality method to identify causal affiliation between the discussed variables.

The remaining portion of the paper is furnished by placing the literature review in section 2, data and methodology in section 3, and empirical results in section 4. Finally, section 5 describes the conclusion and policy recommendations.

\section{LITERATURE REVIEW}

In this section, we discuss previous studies dealing with similar variables in the same perspective. First, we summarize literature that shows the association between renewable energy use and economic growth. A number of researchers displayed a strong long-term connection between renewable energy consumption and economic growth, while others found no affiliation between them. Applying ARDL technique and VECM Granger causality method, Rafindadi and Ozturk (2016) found that a one percent upsurge in renewable energy consumption boosts economic growth by 0.22 percent in Germany all through 1970Q1-2013Q4. Sadorsky (2009) revealed a one percent rise in real income per capita upturns by around $3.5 \%$ the renewable energy consumption per capita in emerging economies. Also, Mahmoodi \& Mahmoodi (2011) got a cointegration relationship between these variables in seven Asian developing countries during 1985-2007. Bhattacharya et al., (2016) showed renewable energy use has a major positive influence on the economic output of 57 percent of 38 top renewable energy consuming countries for the duration of 1991-2012. Koçak and Şarkgüneşi (2017) found the consumption of renewable energy influences economic growth positively and their results support the feedback hypothesis using the panel cointegration method in 9 black 


\section{Equation Model"}

counties and Balkan countries in 1990-2012. Fotourehchi (2017) also found a long-run positive causality running from renewable energy to real GDP in 42 developing countries in the course of 1990-2012. Also, Chang et al., (2015) found the presence of a bi-directional causal association between economic growth and renewable energy in G7 countries using the causality approach introduced by Emirmahmutoglu and Kose (2011). Likewise, Arifin and Syahruddin (2011) showed that Granger causality runs merely from renewable electrical energy use per capita to GDP per capita in the case of Indonesia using Toda-Yamamoto and Engle-Granger procedure. Soava et al. (2018) found that renewable energy consumption positively influences the economic growth of 28 EU countries during 1995-2015 using panel cointegration method. When applying ARDL methodology and the VECM Granger causality method, Hung-Pin (2014) found no influence of renewable energy conservation on economic growth in France, Spain, Portugal, and Denmark among OECD countries throughout 1982-2011.

Furthermore, several authors added more variables with renewable energy consumption and economic growth to identify causal affiliation between them. Applying the ARDL model and the VECM Granger causality technique, Shahbaz et al., (2015) found cointegrated relationships between renewable energy consumption, economic growth, labor, and capital; renewable energy consumption and labor boost economic growth in Pakistan. Using similar variables, Alper and Oguz (2016) explored that renewal energy use positively impacts economic growth in new EU member countries. Applying a similar methodology, Sebri and Ben-Salha (2014) revealed the importance of renewable energy in boosting economic growth in BRICS nations during 1971-2010. Also, Marinas et al., (2018) captured causal associations among renewable energy consumption, Economic growth, development and investment in human capital in Central and Eastern European countries (CEE) in 1990-2014. Lin and Moubarak (2014) explained in their study that there is potential for a flourishing renewable energy sector in China that can help boost economic growth. Similarly, renewable energy use is influenced by labor in the short run, however no proof of causality was found between carbon emissions and renewable energy use. Meaning, the amount of renewable energy in China is not significant and not extensively utilized to mitigate the carbon dioxide emissions related issues. Moreover, Menyah and Wolde-Rufael (2010) revealed nuclear-powered energy use can assist in mitigation of $\mathrm{CO}_{2}$ emissions, but up to now, renewable energy use has not touched the level to make a major composition to decrease emissions in the USA during 1960-2007. Using GMM and the 2SLS approach, Ozturk and Al-Mulali (2015) observed the causal connection between GDP, urbanization, energy consumption, trade openness, and $\mathrm{CO}_{2}$ emissions in Cambodia in 1996-2012, but they did not confirm the EKC hypothesis. Where Boluk and Mert (2015) found renewable electricity decrease will help environmental improvement with a one-year lag. Furthermore, they proposed a U-shaped (EKC) connection between per capita GHGs and income in Turkey during 1961-2010. Similarly, Danish and Wang (2017) showed the presence of the EKC in Pakistan during 1970-2012. Using the DOLS and VECM approach, Eren, Taspinar, and Gokmenoglu (2019) found economic growth and financial development significantly and positively influenced renewable energy consumption in India during 1971-2015.

Secondly, we discuss literature that shows the association between economic growth and human development index (HDI). Ranis, Stewart, and Ramirez (2007) found an important connection in both directions from EG to HD and from the HD to EG chain using cross country regression. Similarly, Costantini and Monni (2008) showed the significance of high institutional quality and investments for human capital formation to create a sustainable development pathway using the Resource Curse Hypothesis $(\mathrm{RCH})$ and EKC model. Khodabakshi (2011) analyzed GDP and three indicators of human development in India during 1980-2010 in their study. Using Cross sectional growth regression model, Ghosh (2006) found human development induces a growth process in 15 major Indian states. Grubaugh (2015) applied a dynamic panel model to analyze the affiliation between economic growth and HDI. Davies and Quinlivan (2006) used GMM technique in a panel data context and found that increases in trade and per capita income are positively related to the upcoming increase in social wellbeing. Sinha and Sen (2016) investigated the causal connection between economic growth, $\mathrm{CO}_{2}$ emissions, trade volume, and human development indicator using GMM approach in BRIC countries and found the presence of EKC during 1980-2013. They said BRIC countries have to emphasize on green energy production.

Finally, we deliberate literature that shows the association between renewable energy use and human development index (HDI). Using panel data regression models in seven EU countries, Pirlogea (2012) found extreme energy dependency of a country triggers pressures to its HD. Ouedraogo (2013) revealed a one percent upsurge in per capita energy use decreases the HDI by 0.8 percent and a one percent rise in per capita electricity consumption upturns the HDI by 0.22 percent. Additionally, a one percent proliferation in energy price lessens the HDI by approximately 0.11 percent in 15 developing countries for the duration of 1988-2008.

In the case of Bangladesh, very little attention was given to identify the association between renewable energy use, economic growth, and HDI. Sarker and Alam (2010) applied the Granger causality test and found merely unidirectional causality association subsists between electricity generation and economic growth in Bangladesh during 1973-2006. Using Bootstrap causality test Hatem-J and Shamsuddin (2016) found no significant causality running from financial 


\section{Equation Model"}

development on human development in Bangladesh. However, Alam, Ahmed, and Begum (2017) used the maximum entropy bootstrap method and found a unidirectional causality runs from economic growth to energy demand which indicates that conservative policy might not harm the Bangladesh economy. Therefore, the uniqueness of the current study is to examine the affiliation between renewable energy use, real GDP per capita, and HDI including urbanization, environmental factor, and trade liberalization as control variables to eliminate specification bias.

\section{DATA AND METHODOLOGY}

\subsection{Data}

The pragmatic assessment of the study is carried out by applying yearly data throughout 1990-2015 in the fact of Bangladesh. Data about renewable energy use, per capita $\mathrm{CO}_{2}$ emissions, real GDP, trade liberalization, and urbanization are put together from the World Development Indicators (WDI) of the World Bank, and the data on human development is collected from the Human Development Report of the World Bank (2020). Human development is assessed as the value of the human development index (HDI). HDI is assessed by three aspects such as health, education, and living standard. Renewable energy use is calculated as the percentage of renewable energy in total final energy consumption, where renewable energy is the substitute of wind, hydro and solar energy. Real GDP per capita is assessed in constant 2010 US dollar. Real GDP per capita is a proxy variable of Economic growth. Carbon dioxide emissions are applied in this study as a proxy variable of environmental situation and determined by per capita metric tons. Carbon dioxide emissions are the exhausts stemming from the burning of fossil fuels and the production of cement. Urban population refers to people living in the urban areas. Urbanization is measured by the growth rate of the urban population. Trade liberalization is the sum of exports and imports of goods and services measured as a share of gross domestic product (GDP). Descriptions of all the stated variables are collected from the World Bank.
Along with independent variables, some control variables are included in the model e.g. trade openness, environmental factors, and urbanization which also shape the human development process. These control variables are taken because they are connected to the independent variables such as renewable energy and economic growth. To explain more, economic growth has a positive influence on trade and HDI (Davies and Quinlivan, 2006). Again, trade facilitates income generating activities that raises per capita income. Along with the increase in per capita income, the standard of living goes up as a result of availability and affordability of better health and education derived from increased income levels. On the other hand, environmental factors, e.g. carbon emission, play an imperative role in the human development process in lifting up the global health issues. In particular, $\mathrm{CO}_{2}$ emission of BRICS countries has enhanced the human development process (Sinha and Sen, 2016, Zaman et al., 2016) while some other countries experienced the opposite phenomenon. Furthermore, renewable energy consumption, economic growth, and $\mathrm{CO}_{2}$ emissions are positively related to each other (Danish et al., 2017). Finally, human development is shaped by urbanization as it offers an improved health and education system and income opportunities to the urban people as compared to the countryside residents.

As shown in figure 1, in terms of the Human Development Index (HDI), Bangladesh experienced a constant sharp rise during 1990-2015 starting at 0.4 in 1990 that reached above 0.55 in 2015. Like HDI, economic growth had a steady increase at an upward moving straight line in the period 19902015. In contrast, renewable energy use dropped to the bottom in the fifteen years period. With the pace of economic growth, $\mathrm{CO}_{2}$ emission climbed dramatically at an alarming rate; in 1990 it had only below 0.2 metric tons per capita that increased to above 0.4 metric tons per capita. Trade openness, another important variable of the study, gives us an unstable rising graph; it rose till 2000 and had a slice decline till 2005, again rose till 2010 and finally started to decline in 2015 after a small increase. While considering urbanization, it declined dramatically in the first five years and continued until 2000. In 2005, it picked to the top and again declined to the bottom in 2015.

Figure 1: The plots of human development index and explanatory variables in the case of Bangladesh, 1990-2015.
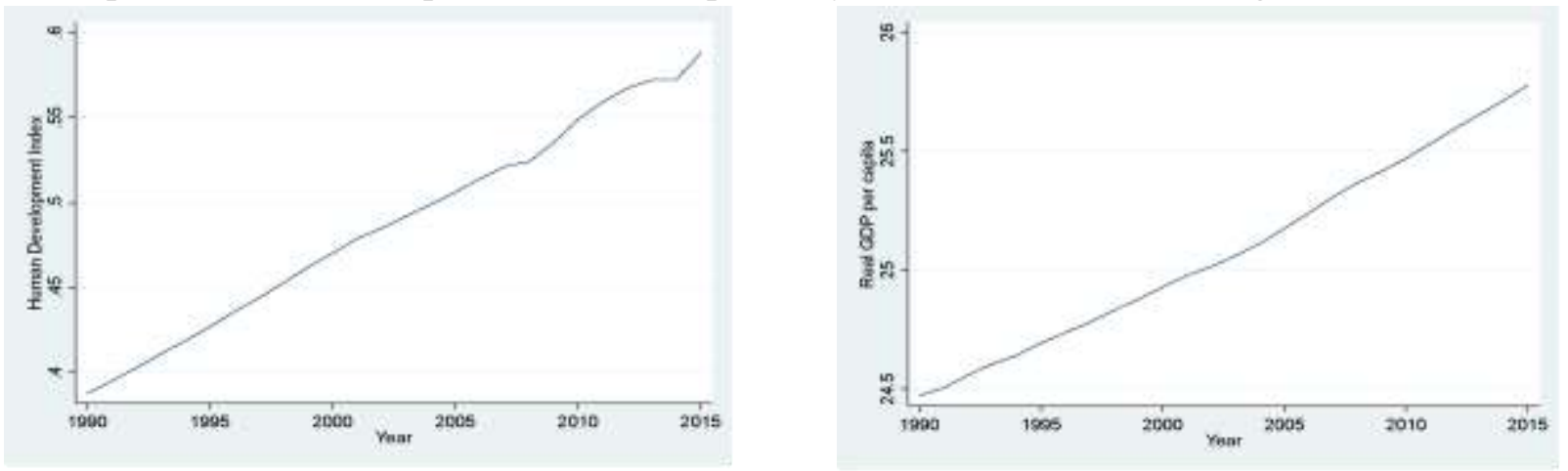

Human development (HDI, the value of human development index) Real GDP (GDP, in constant 2010 USD) 


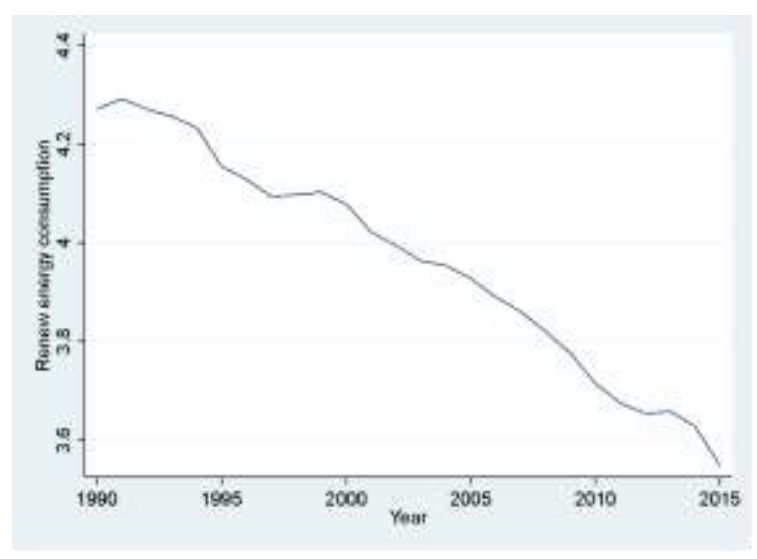

Renewable energy use

(REU, in percentage of renewable energy

in total final energy consumption)

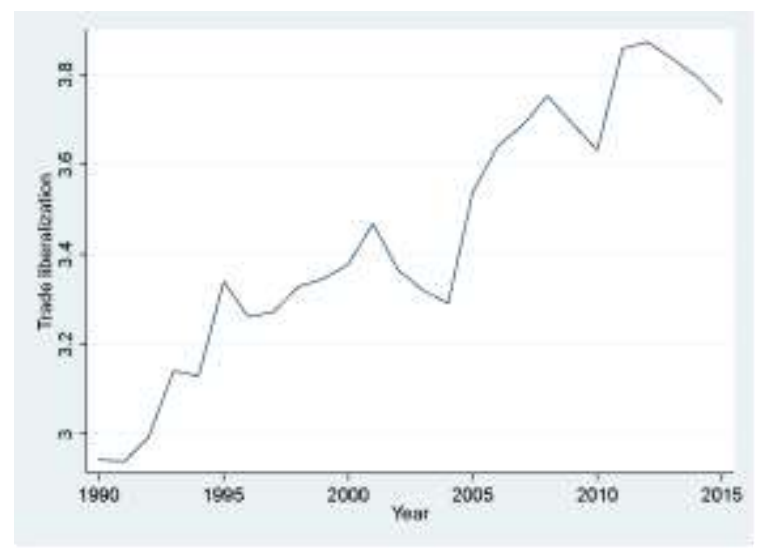

Trade liberalization (TL, measured using exports and imports as a share of GDP)

Source: Assembled from the World Bank, Bangladesh.

\subsection{Methodology}

This section summarizes econometric methods such as the 2SLS regression model and vector error correction technique employed in this study with a view to examining the association between human development and explanatory variables.

In the study, we apply a single multivariate structure to inspect the affiliation between HDI, renewable energy use, real GDP incorporating $\mathrm{CO}_{2}$ emissions, trade liberalization, and urbanization. We follow the pragmatic study of Wang et al. (2018). The linear representation of the model can be expressed as:

$$
\ln H D I_{t}=\theta_{0}+\varphi_{1} G D P_{t}+\varphi_{2} R E U_{t}+\varphi_{3} C O_{2 t}+\varphi_{4} T L_{t}+\varphi_{5} U R B_{t}+\varepsilon_{f}
$$

Where

lnHDI = Natural logarithm of human development index;

$\operatorname{lnGDP}=$ Natural logarithm of real GDP per capita;

$\operatorname{lnREU}=$ Natural logarithm of renewable energy use;

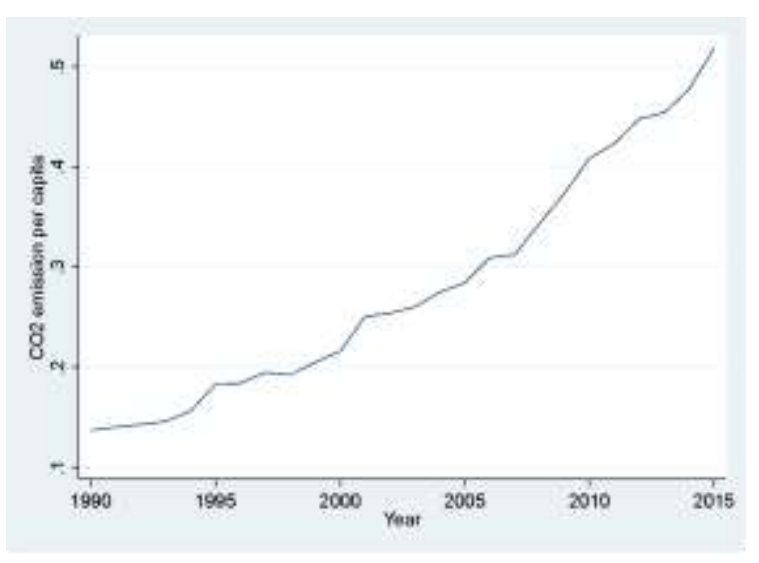

$\mathrm{CO}_{2}$ emissions

$\left(\mathrm{CO}_{2}\right.$, in metric tons per capita)

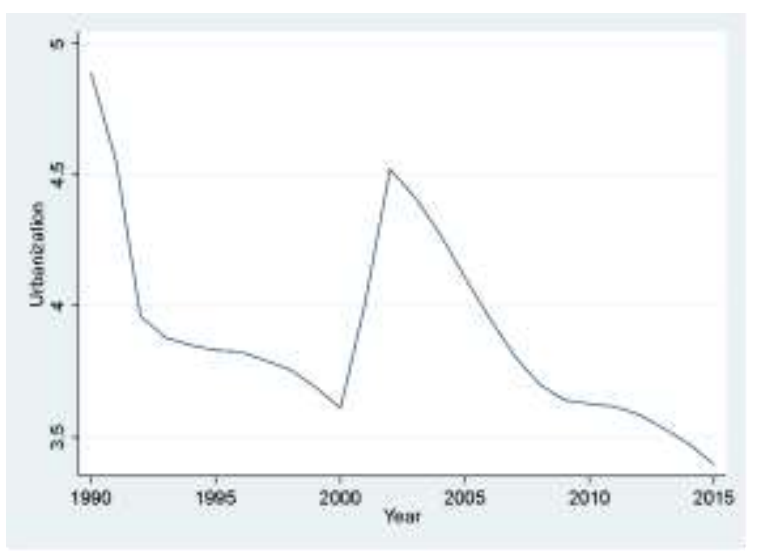

Urbanization (URB, measured by the growth rate of urban population)

$\operatorname{lnCO} \mathrm{CO}_{2}=$ Natural logarithm of per capita $\mathrm{CO}_{2}$ emission as a proxy variable of environmental condition;

$\operatorname{lnTL}=$ Natural logarithm of trade liberalization; $\ln U R B=$ Natural logarithm of urbanization; and $\varepsilon=$ error term.

\subsubsection{Two-stage least square model (2SLS)}

In order to examine the linkage between HDI and independent variables, a two-stage least square technique (2SLS) has been applied in this study. Previously, the 2SLS model is applied in numerous research in order to evaluate the time series data (Wang et al., 2018). Generally, econometrics methods e.g. cointegration may give inconsistent results in using small sample size data. Moreover, a model is considered to be highly correlated when a number of macroeconomic variables is applied. In this case, the issue of multicollinearity may appear due to the correlation between the regressors and the disturbance term. Consequently, spurious estimates may be found using the ordinary least 
square method. In order for controlling correlation among variables, we need a regression model. Numerous regression methods can be used as important tools to address the problem, for instance 2 SLS regression model suggested by Cumby et al., in 1983. The 2SLS method can be used if the endogenous variables correlate with the residuals as an extension of the OLS technique. In this study, we have used 26 years of data (1990-2015) which is considered to be small in size and applied macroeconomic variables. In this case, multicollinearity issues may arise due to the correlation between the dependent variables and residuals. Thus, to examine the association between the analyzed variables, we apply two step least square (2SLS) model in this study.

\subsubsection{Vector error correction model}

The vector error correction model is instrumental for time series data analysis in examining the result of one variable on another. Therefore, we apply the VECM Granger causality model to inspect the causal linkage among discussed variables in the study. Initially, the error correction term (ECM) is determined, afterward the regression model is run along with ECM. When we get the negative and significant value of ECM, it implies that the long-term causality between the discussed variables. Finally, the study calculates the Wald statistic for all regressors with ECM. VECM Granger causality is described in the below-mentioned equation:

$$
\left[\begin{array}{l}
\ln H D I \\
\ln G D P \\
\ln R E U \\
\ln C O_{2} \\
\ln T L \\
\ln U R B
\end{array}\right]=\left[\begin{array}{l}
\alpha_{1} \\
\alpha_{2} \\
\alpha_{3} \\
\alpha_{4} \\
\alpha_{5} \\
\alpha_{5}
\end{array}\right]+\left[\begin{array}{llllll}
\alpha_{11 k} & \alpha_{12 k} & \alpha_{13 k} & \alpha_{14 k} & \alpha_{15 k} & \alpha_{16 k} \\
\alpha_{21 k} & \alpha_{22 k} & \alpha_{23 k} & \alpha_{24 k} & \alpha_{25 k} & \alpha_{26 k} \\
\alpha_{31 k} & \alpha_{32 k} & \alpha_{33 k} & \alpha_{34 k} & \alpha_{35 k} & \alpha_{36 k} \\
\alpha_{41 k} & \alpha_{42 k} & \alpha_{43 k} & \alpha_{44 k} & \alpha_{45 k} & \alpha_{46 k} \\
\alpha_{51 k} & \alpha_{52 k} & \alpha_{53 k} & \alpha_{54 k} & \alpha_{55 k} & \alpha_{56 k} \\
\alpha_{61 k} & \alpha_{62 k} & \alpha_{63 k} & \alpha_{64 k} & \alpha_{65 k} & \alpha_{66 k}
\end{array}\right]+\left[\begin{array}{c}
\Delta \ln H D I_{i t} \\
\Delta \ln G D P_{i t} \\
\Delta \ln R E U_{i t} \\
\Delta \ln C O_{2 i t} \\
\Delta \ln T L_{i t} \\
\Delta \ln U R B_{i t}
\end{array}\right]+\left[\begin{array}{l}
\gamma_{1} \\
\gamma_{2} \\
\gamma_{3} \\
\gamma_{4} \\
\gamma_{5} \\
\gamma_{6}
\end{array}\right] E_{i t-1}+\left[\begin{array}{l}
\mu_{1} \\
\mu_{2} \\
\mu_{3} \\
\mu_{4} \\
\mu_{5} \\
\mu_{6}
\end{array}\right]_{(2)}
$$

Where, $\mathrm{t}$ represents time period, $E C M_{i t-1}$ is the one period lag error correction term, and $\mu_{i t}$ specifies the disturbance term.

\section{RESULTS AND DISCUSSION}

In this section, we present and discuss the results. First, we look at descriptive statistics and pairwise correlation matrix. Then, we conduct the ordinary least square method, 2SLS model, and GMM technique. Finally, we discuss the VECM Granger causality method to scrutinize the causal association between the variables.
Table 1 presents the descriptive statistics of the study. All the variables are expressed in level form. We know that skewness and kurtosis define the shape of a probability distribution. As indicated by the results of mean, standard deviation, skewness, and kurtosis, we are in a position to consider our data to be correct from all aspects.

Table 1: Results of Descriptive statistics

\begin{tabular}{|l|l|l|l|l|}
\hline Variables & Mean & Standard deviation & Skewness & Kurtosis \\
\hline HDI & 0.4873 & 0.0606 & -0.0105 & 1.832 \\
\hline GDP & 8.420 & 3.430 & 0.6280 & 2.213 \\
\hline REU & 53.97 & 11.91 & 0.0603 & 1.830 \\
\hline $\mathrm{CO}_{2}$ & 0.2805 & 0.1172 & 0.5265 & 2.047 \\
\hline $\mathrm{TL}$ & 32.57 & 9.149 & 0.2287 & 1.823 \\
\hline URB & 3.897 & 0.3667 & 1.093 & 3.549 \\
\hline
\end{tabular}

Source: Computed by authors.

Next, we accomplish the pairwise correlation between the variables. Table 2 depicts the pairwise correlation matrix. HDI is highly positively correlated with real GDP per capita, carbon emissions, and trade liberalization, but negatively correlated with renewable energy use and urbanization. Renewable energy use is highly negatively correlated with all variables except urbanization. $\mathrm{CO}_{2}$ emissions are positively correlated with HDI, GDP, and trade, while negatively correlated with renewable energy use and urbanization. Finally, urbanization is negatively correlated with all variables except renewable energy use. 
Table 2: correlation matrix

\begin{tabular}{|c|c|c|c|c|c|c|}
\hline Variables & $\operatorname{lnHDI}$ & $\operatorname{lnGDP}$ & $\operatorname{lnREU}$ & $\operatorname{lnCO} 2$ & $\operatorname{lnTO}$ & $\operatorname{lnURB}$ \\
\hline $\operatorname{lnHDI}$ & 1.000 & & & & & \\
\hline $\operatorname{lnGDP}$ & 0.9911 & 1.000 & & & & \\
\hline lnREU & -0.9858 & -0.9952 & 1.000 & & & \\
\hline $\operatorname{lnCO} 2$ & 0.9932 & 0.9958 & -0.9963 & 1.000 & & \\
\hline $\operatorname{lnTL}$ & 0.9513 & 0.9480 & -0.9422 & 0.9488 & 1.000 & \\
\hline $\ln U R B$ & -0.5922 & -0.6108 & 0.5977 & -0.5828 & -0.6780 & 1.000 \\
\hline
\end{tabular}

Source: Computed by authors.

Then, we perform a unit root test. We apply two different unit root tests; they are the Augmented Dickey-Fuller (ADF) test and Phillips-Perron (PP) test. The outcomes are displayed in Table 3. From the findings, it is found that all variables have a unit root at the level but become stationary after the first difference. Both the ADF test and PP test give the same results. Therefore, we can apply the VECM Granger causality method in the study to inspect the causal linkage between the analyzed variables.

Table 3: Results of Unit root Test

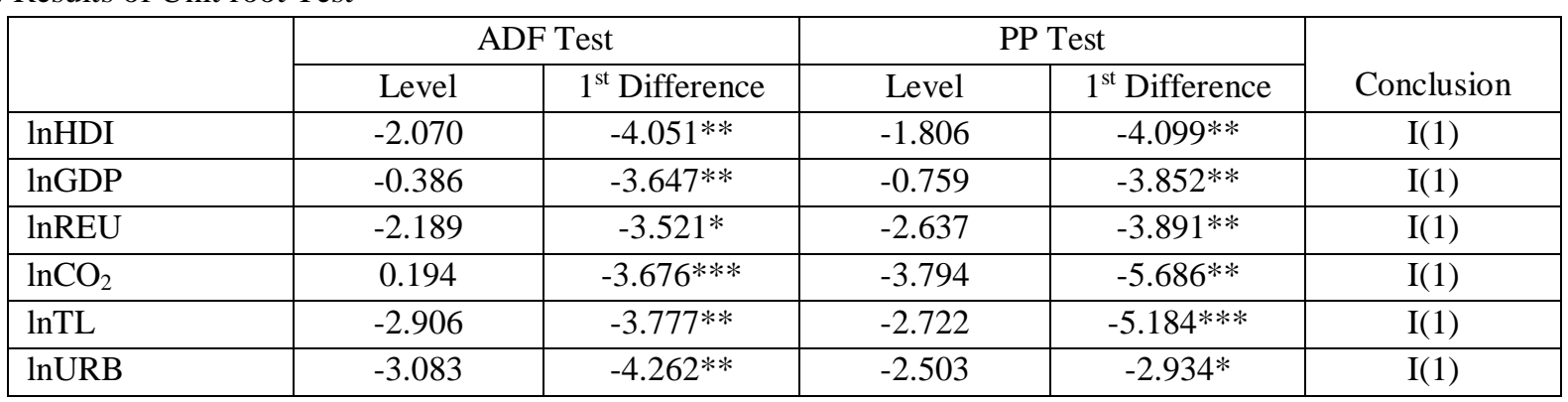

Source: Computed by authors. ***,**, * represent levels of significance $1 \%, 5 \%$, and $10 \%$ respectively.

Next OLS regression model is considered, and the estimation results are described in Table 4 . In the Table, we see that renewable energy use and carbon dioxide emissions have statistically significant impact on human development index and the remaining of the variables are statistically insignificant. It may be because we get a highly correlated relationship between some of the variables. Therefore, there may exist multicollinearity problems in the model. We assess the variance inflation factor (VIF) to check the existence of multicollinearity problems in the model. As shown in Table 4 , the coefficients of VIF are greater than 10 in all variables except urbanization, which shows a serious multicollinearity problem exists in the model. Thus, we may get biased and unreliable findings using OLS regression technique.

Table 4: Results of OLS regression model (dependent variable: $\ln H D I)$

\begin{tabular}{|l|l|l|l|l|l|}
\hline Variables & Coeffecient & Std. error & t-value & $\mathrm{P}>|\mathrm{t}|$ & VIF \\
\hline $\ln \mathrm{GDP}$ & 0.1445 & 0.0865 & 1.67 & 0.110 & 158.98 \\
\hline $\ln$ REU & $0.3865^{* *}$ & 0.1595 & 2.42 & 0.025 & 173.14 \\
\hline $\ln \mathrm{CO}_{2}$ & $0.3544^{* *}$ & 0.1038 & 3.41 & 0.003 & 252.22 \\
\hline $\ln \mathrm{L}$ & 0.0186 & 0.0360 & 0.52 & 0.610 & 14.20 \\
\hline $\ln \mathrm{RBB}$ & -0.0125 & 0.0481 & -0.26 & 0.796 & 2.50 \\
\hline Constant & $-5.450^{* *}$ & 2.505 & -2.18 & 0.042 & - \\
\hline
\end{tabular}

Source: Computed by authors. $* * *, * *$, represent levels of significance 1\%, 5\%, and 10\% respectively.

To overcome the multicollinearity problem and to get reliable and unbiased results; 2SLS technique is used in this study. The estimated results of the 2SLS model are presented in Table 5. We get statistically significant positive coefficients for real GDP per capita, renewable energy use, and carbon emissions, while insignificant coefficients for trade liberalization and urbanization in respect to human development index (HDI) as a dependent variable. 
Table 5: Result of Simultaneous Two-Stage Least Square (2SLS) method and Generalized Moment method

\begin{tabular}{|l|c|c|c|c|c|c|}
\hline \multirow{2}{*}{ Variables } & \multicolumn{3}{|c|}{ 2SLS Model } & \multicolumn{3}{c|}{ Generalized Moment method } \\
\cline { 2 - 7 } & Coeffecient & Std. error & t-value & Coeffecient & Std. error & t-value \\
\hline $\ln$ GDP & $.1445^{* * *}$ & .0758 & 1.90 & $.1445^{* * *}$ & .0753 & 1.92 \\
\hline $\ln$ REU & $.3865^{* *}$ & .1398 & 2.76 & $.3865 * *$ & .1341 & 2.88 \\
\hline $\ln \mathrm{CO}_{2}$ & $.3544^{* *}$ & .0911 & 3.89 & $.3544 * * *$ & .0912 & 3.89 \\
\hline $\ln \mathrm{TL}$ & .0186 & .0316 & 0.59 & .0186 & .0276 & 0.67 \\
\hline $\ln \mathrm{NRB}$ & -.0125 & .0422 & -0.30 & -.0125 & .0421 & -0.30 \\
\hline Constant & $-5.450^{* *}$ & 2.197 & -2.48 & $-5.451^{*}$ & 2.098 & -2.60 \\
\hline
\end{tabular}

Source: Computed by authors. ***,**, * represent levels of significance 1\%, 5\%, and 10\% respectively.

We get a positive sign and statistically significant coefficient for real GDP per capita at one percent confidence level, which means that a one percent increase in real GDP per capita may significantly raise the human development index by 0.14 percent in Bangladesh holding other variables constant. Economic growth plays a crucial role in the human development process through household and government expenditure on different activities involving human welfare (Ghosh, 2006). In Bangladesh, noticeable upturn in accessibility to education, primary schooling completion, and health facility is observed. The force working behind it may be that the government increases the allocation on education and health in the budget every year.

Renewable energy use carries a positive and statistically significant sign. It implies that REU has a positive and significant impact on HDI; a $1 \%$ increase in renewable energy use may improve HDI by $0.39 \%$ in Bangladesh. This outcome is consistent with Pirlogea, 2012 and Niu et al., 2013 and inconsistent with Ouedraogo, 2013 and Wang et al., 2018. As Pirlogea (2012) detected, renewable energy use positively impacts on HD with no exemption; an estimated coefficient above one was found in the case of Poland and Ireland. Similarly, Islam et al., (2014) discovered that solar home system (SHS) positively influences socio-economic advancement in rural areas as it helps in lessening poverty and widening job opportunities which increases HD process in Bangladesh. Thus, renewable energy use can contribute to the HD process in Bangladesh.

The findings disclose that the coefficient of carbon dioxide emissions is 0.354 ; that is statistically significant at five percent significance level. Therefore, a $1 \%$ proliferation in $\mathrm{CO}_{2}$ emissions may lead to an upsurge human development process by 0.34 percent. The finding is in line with (Wang et al., 2018) who got the same result in terms of Pakistan. As we found in the study, economic growth has a positive impact on HDI which, in turn, helps to increase per capita income enabling people to spend more on food, education, and health. On the other side, the government can allocate more of its budget on public health and education. Thus, economic growth poses multifold positive impact on HDI. On the contrary, according to the EKC hypothesis, $\mathrm{CO}_{2}$ emissions increase with the increase of per capita income. But, after reaching a turning point, $\mathrm{CO}_{2}$ emissions decrease along with the increase of per capita income. The reason may be that growing $\mathrm{CO}_{2}$ emissions enforces policy makers to focus on clean energy. As a result, the environment improves which assures better health accelerating the human development process. The study gets a positive sign, but the statistically insignificant result for trade liberalization. Also, we find a statistically insignificant outcome for urbanization in the model.

In order to examine the robustness of 2SLS technique, the generalized moment method (GMM) is applied; the results are stated in table 5. From the results of GMM, we find that economic growth, renewable energy use and carbon emissions have a positive and significant influence on the HDI. On the other hand, trade liberalization and urbanization have insignificant relation with the human development process. Also, we get almost similar coefficients for every variable applying GMM. Therefore, it is inferred that the outcomes of GMM and 2SLS techniques are the same. Thus, the findings of the study are robust and reliable. Also, we evaluate a number of diagnostic tests of the 2SLS model; results are presented in table 6 .

Table 6: Diagnostic Test

\begin{tabular}{|c|c|c|c|c|c|}
\hline Tests & $\begin{array}{c}\text { Serial } \\
\text { Correlation }\end{array}$ & Heteroscedasticity & $\begin{array}{c}\text { Durbin- } \\
\text { Watson }\end{array}$ & $\begin{array}{c}\text { Normality } \\
\text { Adjusted- } \\
\mathrm{R}^{2}\end{array}$ \\
\hline Coefficients & 0.108 & 0.571 & 1.81 & 0.701 & 0.988 \\
\hline
\end{tabular}

Source: Computed by authors.

We accomplish Durbin Watson test, Breusch-Godfrey LM test, Skewness and Kurtosis of residuals test, and $\chi^{2}-\mathrm{ARCH}$ test to examine the endogeneity, serial correlation, normality, and heteroscedasticity in the model. The outcomes fail to reject the null hypothesis. Thus, there is no endogeneity, no serial correlation, no heteroscedasticity, and normality of 


\section{Equation Model"}

disturbances in the model. In addition, high $\mathrm{R}^{2}$ value suggests that the model is relatively perfect.

Next, we apply the VECM Granger causality method in the study to scrutinize the causal association between analyzed variables; results are given in Table 7 . We find a long-run causal association between HDI and urbanization. This indicates that HD process is affected by urbanization in Bangladesh. The remaining variables do not have causal connection with HDI in the long-run. With regard to shortrun causality, HDI has bidirectional causality with economic growth and renewable energy use. Also, HDI and trade liberalization Granger cause each other in the background of Bangladesh. This result is in line with Wang et al. (2018). They also found HD and trade openness Granger cause for each other in case of Pakistan.

Table 7: Results of VECM Granger causality analysis

\begin{tabular}{|c|c|c|c|c|c|c|c|}
\hline \multirow[t]{2}{*}{ Variables } & \multicolumn{6}{|c|}{ Short-run results } & \multirow{2}{*}{$\begin{array}{l}\begin{array}{l}\text { Long-run } \\
\text { results }\end{array} \\
\text { ECM }_{\mathrm{t}-1}\end{array}$} \\
\hline & $\operatorname{lnHDI}$ & $\operatorname{lnGDP}$ & $\ln R E U$ & $\operatorname{lnCO} 2$ & $\operatorname{lnTL}$ & $\operatorname{lnURB}$ & \\
\hline $\ln \mathrm{HDI}$ & - & $\begin{array}{l}-.432 * * \\
(.191)\end{array}$ & $\begin{array}{l}-.157^{*} \\
(.081)\end{array}$ & $\begin{array}{l}-.026 \\
(.051)\end{array}$ & $\begin{array}{l}.008 \\
(.013)\end{array}$ & $\begin{array}{l}-.047 \\
(.030)\end{array}$ & $\begin{array}{l}-.052 \\
(.072)\end{array}$ \\
\hline $\operatorname{lnGDP}$ & $\begin{array}{l}-.107 \\
(.308)\end{array}$ & - & $\begin{array}{l}.109 \\
(.106)\end{array}$ & $\begin{array}{l}.100 \\
(.066)\end{array}$ & $\begin{array}{l}-.028 \\
(.017)\end{array}$ & $\begin{array}{l}-.058 \\
(.039)\end{array}$ & $\begin{array}{l}.159 * \\
(.093)\end{array}$ \\
\hline $\operatorname{lnREU}$ & $\begin{array}{l}1.17 \\
(.860)\end{array}$ & $\begin{array}{l}-.658 \\
(.692)\end{array}$ & - & $\begin{array}{l}.284 \\
(.185)\end{array}$ & $\begin{array}{l}.037 \\
(.049)\end{array}$ & $\begin{array}{l}-.096 \\
(.111)\end{array}$ & $\begin{array}{l}.750 * * \\
(.261)\end{array}$ \\
\hline $\operatorname{lnCO} 2$ & $\begin{array}{l}-.672 \\
(2.10)\end{array}$ & $\begin{array}{l}1.09 \\
(1.68)\end{array}$ & $\begin{array}{l}-.371 \\
(.721)\end{array}$ & - & $\begin{array}{l}.021 \\
(.121)\end{array}$ & $\begin{array}{l}.143 \\
(.270)\end{array}$ & $\begin{array}{l}-.937 \\
(.639)\end{array}$ \\
\hline $\operatorname{lnTL}$ & $\begin{array}{l}7.44 * \\
(4.25)\end{array}$ & $\begin{array}{l}1.53 \\
(3.42)\end{array}$ & $\begin{array}{l}.135 \\
(1.46)\end{array}$ & $\begin{array}{l}-.212 \\
(.918)\end{array}$ & $\begin{array}{l}-.220 \\
(.246)\end{array}$ & - & $\begin{array}{l}-.261 \\
(1.29)\end{array}$ \\
\hline $\ln U R B$ & $\begin{array}{l}2.46 \\
(1.61)\end{array}$ & $\begin{array}{l}3.12 \\
(1.29)\end{array}$ & $\begin{array}{l}-.553 \\
(.554)\end{array}$ & $\begin{array}{l}-.411 \\
(.348)\end{array}$ & - & $\begin{array}{l}.717 \\
(.208)\end{array}$ & $\begin{array}{l}-1.35 * * \\
(.491)\end{array}$ \\
\hline
\end{tabular}

Source: Computed by authors. ***,**, * represent levels of significance $1 \%, 5 \%$, and $10 \%$ respectively.

\section{CONCLUSION}

This paper tries to seek out the correlation between renewable energy use, real GDP per capita and HDI in addition to trade openness, urbanization and environmental aspects in case of Bangladesh during the phase of 1990-2015. In persuasion of the objective, time series data of the given period is analyzed by means of the 2SLS approach. In order to find the underlying relationship between the given variables of the study, we use VECM Granger causality technique. Findings of the study suggest that real GDP per capita, $\mathrm{CO}_{2}$ emissions, and the use of renewable energy have phenomenal positive consequences on human development index while trade liberalization and urbanization incur insignificant association. The study also shows that HDI has bidirectional causality with real GDP and renewable energy use.

The results found in the study put forward several crucial recommendations. In the study, we uncover that real GDP strengthens the human development process. In order to upgrade the HDI, the government should increase its budget allocation on health and education and ensure efficient monitoring and transparency in the implementation of the projects. We also find that an increase in renewable energy use raises the Human Development Index. Therefore, the government should emphasize on the renewable energy production and the use of renewable energy. With the purpose of encouraging the people to use clean energy, stimulus packages should be introduced. Tax on producing renewable energy and import of clean energy equipment and raw materials should be kept at a very minimum level. A certain percentage of green energy use in all households and industry should be made mandatory. Also, Bangladesh is situated in the tropical region of the world where it gets strong sunlight almost year round offering an immense possibility of collecting solar energy at almost no cost.

The GDP of the country is increasing every year. The average GDP growth rate was $6.55 \%$ in the last ten years (2009-2019). This increasing GDP may be taken as a great opportunity to pull the HDI to a better level. A higher GDP offers a greater affordability of health and education for both government and people. Unless the government is successful enough in improving the HDI utilizing the opportunity of higher GDP, the existing economic growth will never be sustainable.

\section{REFERENCE}

1. Ahmed, M., \& Shimada, K. (2019). The Effect of Renewable Energy Consumption on Sustainable Economic Development: Evidence from Emerging and Developing Economies. Energies, 12(15). doi:10.3390/en12152954

2. AhAtil, A., Bouheni, F.B., Lahiani, A., \& Shahbaz, M. (2019). Factors influencing CO2 Emission in China: A Nonlinear Autoregressive Distributed 
Lags Investigation. MPRA paper no. 91190. https://mpra.ub.uni-muenchen.de/91190/

3. Alam, M. J., Ahmed, M., \& Begum, I. A. (2017). Nexus between non-renewable energy demand and economic growth in Bangladesh: Application of Maximum Entropy Bootstrap approach. Renewable and Sustainable Energy Reviews, 72, 399-406. doi:10.1016/j.rser.2017.01.007

4. Alper, A., \& Oguz, O. (2016). The role of renewable energy consumption in economic growth: Evidence from asymmetric causality. Renewable and Sustainable Energy Reviews, 60, 953-959. doi:10.1016/j.rser.2016.01.123

5. Apergis, N., \& Payne, J. E. (2010). Renewable energy consumption and economic growth: Evidence from a panel of OECD countries. Energy Policy, 38(1), 656-660. doi:10.1016/j.enpol.2009.09.002

6. Apergis, N., Payne, J. E., Menyah, K., \& WoldeRufael, Y. (2010). On the causal dynamics between emissions, nuclear energy, renewable energy, and economic growth. Ecological Economics, 69(11), 2255-2260. doi:10.1016/j.ecolecon.2010.06.014

7. Arifin, J., \& Syahruddin, N. (2011). Causality relationship between renewable and non-renewable energy consumption and GDP in Indonesia. Economics and Finance in Indonesia, 59 (1): 1-18.

8. Behera, J., \& Mishra, A. K. (2019). Renewable and non-renewable energy consumption and economic growth in G7 countries: evidence from panel autoregressive distributed lag (P-ARDL) model. International Economics and Economic Policy, 17(1), 241-258. doi:10.1007/s10368-019-00446-1

9. Bhattacharya, M., Paramati, S. R., Ozturk, I., \& Bhattacharya, S. (2016). The effect of renewable energy consumption on economic growth: Evidence from top 38 countries. Applied Energy, 162, 733741. doi:10.1016/j.apenergy.2015.10.104

10. Bölük, G., \& Mert, M. (2015). The renewable energy, growth and environmental Kuznets curve in Turkey: An ARDL approach. Renewable and Sustainable Energy Reviews, 52, 587-595. doi:10.1016/j.rser.2015.07.138

11. BP Statistical Review (2020). Statistical Review of World Energy. Available at: https://www.bp.com/en/global/corporate/energyeconomics/statistical-review-of-worldenergy/renewable-energy.html

12. Can, H., \& Korkmaz, Ö. (2019). The relationship between renewable energy consumption and economic growth. International Journal of Energy Sector Management, 13(3), 573-589. doi:10.1108/ijesm-11-2017-0005
13. Chang, T., Gupta, R., Inglesi-Lotz, R., SimoKengne, B., Smithers, D., \& Trembling, A. (2015). Renewable energy and growth: Evidence from heterogeneous panel of G7 countries using Granger causality. Renewable and Sustainable Energy Reviews, 52, 1405-1412. doi:10.1016/j.rser.2015.08.022

14. Costantini, V., \& Monni, S. (2008). Environment, human development and economic growth. Ecological Economics, 64(4), 867-880. doi:10.1016/j.ecolecon.2007.05.011

15. Cumby, R.E., Huizinga, J., Obstfeld, M. (1983). Two-step two-stage least squares estimation in models with rational expectations. Journal of Econometrics, 21, 333-355.

16. Danish, \& Wang, Z. (2017). Role of Renewable Energy and Non-Renewable Energy consumption on EKC: Evidence from Pakistan. Journal of Cleaner Production, doi:10.1016/j.jclepro.2017.03.203

17. Davies, A., \& Quinlivan, G. (2006). A panel data analysis of the impact of trade on human development. The Journal of Socio-Economics, 35(5), 868-876. doi:10.1016/j.socec.2005.11.048

18. Dogan, E. (2015). The relationship between economic growth and electricity consumption from renewable and non-renewable sources: A study of Turkey. Renewable and Sustainable Energy Reviews, 52, 534-546. doi:10.1016/j.rser.2015.07.130

19. Dogan, E. (2016). Analyzing the linkage between renewable and non-renewable energy consumption and economic growth by considering structural break in time-series data. Renewable Energy, 99, 1126-1136. doi:10.1016/j.renene.2016.07.078

20. Eren, B. M., Taspinar, N., \& Gokmenoglu, K. K. (2019). The impact of financial development and economic growth on renewable energy consumption: Empirical analysis of India. Sci Total Environ, 663, 189-197. doi:10.1016/j.scitotenv.2019.01.323

21. Fotourehchi, Z. (2017). Renewable Energy Consumption and Economic Growth: A Case Study for Developing Countries. International Journal of Energy Economics and Policy, ISSN: 2146-4553, 7(2), 61-64.

22. Grammy, A. P., \& Assane, D. (1997). New Evidence on the effect of human capital on economic growth. Applied Economics Letters, 4(2), 121-124. doi:10.1080/758526709

23. Ghosh, M. (2006). Economic Growth and Human Development in Indian States. Economic and Political Weekly, Vol. 41, No. 30, pp. 3321$3327+3329$. 
24. Grubaugh, S. G. (2015). Economic Growth and Growth in Human Development. Applied Econometrics and International Development, Vol. 15-2.

25. Hatemi-J, A., \& Shamsuddin, M. (2016). The causal interaction between financial development and human development in Bangladesh. Applied Economics Letters, 23(14), 995-998. doi:10.1080/13504851.2015.1128066

26. Hou, J., Walsh, P. P., \& Zhang, J. (2019). The dynamics of Human Development Index. The Social Science Journal, 52(3), 331-347. doi:10.1016/j.soscij.2014.07.003

27. Hung-Pin, L. (2014). Renewable energy consumption and economic growth in nine OECD countries: bounds test approach and causality analysis. ScientificWorldJournal, 2014, 919167. doi:10.1155/2014/919167

28. Inglesi-Lotz, R. (2016). The impact of renewable energy consumption to economic growth: A panel data application. Energy Economics, 53, 58-63. doi:10.1016/j.eneco.2015.01.003

29. Islam, M. T., Shahir, S. A., Uddin, T. M. I., \& Saifullah, A. Z. A. (2014). Current energy scenario and future prospect of renewable energy in Bangladesh. Renewable and Sustainable Energy Reviews, 39, 1074-1088. doi:10.1016/j.rser.2014.07.149

30. Kahia, M., Ben Aïssa, M. S., \& Charfeddine, L. (2016). Impact of renewable and non-renewable energy consumption on economic growth: New evidence from the MENA Net Oil Exporting Countries (NOECs). Energy, 116, 102-115. doi:10.1016/j.energy.2016.07.126

31. Kazar, G., \& Kazar, A. (2014). The Renewable Energy Production-Economic Development Nexus. International Journal of Energy Economics and Policy, Vol. 4, No. 2, pp.312-319, ISSN: 2146-4553.

32. Khodabakhshi, A. (2011). Relationship between GDP and Human Development Indices in India. International Journal of Trade, Economics and Finance, Vol. 2, No. 3.

33. Koçak, E., \& Şarkgüneşi, A. (2017). The renewable energy and economic growth nexus in Black Sea and Balkan countries. Energy Policy, 100, 51-57. doi:10.1016/j.enpol.2016.10.007

34. Kumar De, U., \& Pal, M. (2011). Dimensions of Globalization and Their Effects on Economic Growth and Human Development Index. Asian Economic and Financial Review, 1(1), pp: 1-13.

35. Lin, B., \& Moubarak, M. (2014). Renewable energy consumption - Economic growth nexus for China. Renewable and Sustainable Energy Reviews, 40, 111-117. doi:10.1016/j.rser.2014.07.128
36. Marinas, M. C., Dinu, M., Socol, A. G., \& Socol, C. (2018). Renewable energy consumption and economic growth. Causality relationship in Central and Eastern European countries. PLoS One, 13(10), e0202951. doi:10.1371/journal.pone.0202951

37. Mahmoodi, M., \& Mahmoodi, E. (2011). Renewable Energy Consumption and Economic Growth: The Case of 7 Asian Developing Countries. American Journal of Scientific Research, ISSN 1450-223X, 35, pp.146-152.

38. Masud, M. H., Nuruzzaman, M., Ahamed, R., Ananno, A. A. \& Amanullah Tomal, A. N. M. (2020). Renewable energy in Bangladesh: current situation and future prospect. International Journal of Sustainable Energy, 39:2, 132-175, DOI: 10.1080/14786451.2019.1659270

39. Mele, M. (2019). Renewable Energy Consumption: The Effects on Economic Growth in Mexico. International Journal of Energy Economics and Policy, 9(3), 269-273. doi:10.32479/ijeep.7460

40. Menegaki, A. N. (2011). Growth and renewable energy in Europe: A random effect model with evidence for neutrality hypothesis. Energy Economics, 33(2), 257-263. doi:10.1016/j.eneco.2010.10.004

41. Menyah, K., \& Wolde-Rufael, Y. (2010). CO2 emissions, nuclear energy, renewable energy and economic growth in the US. Energy Policy, 38(6), 2911-2915. doi:10.1016/j.enpol.2010.01.024

42. Metcalfe, I. (2003). Environmental concerns for Bangladesh*. South Asia: Journal of South Asian Studies, 26(3), 423-438. Doi:10.1080/0085640032000178961

43. Niu, S., Jia, Y., Wang, W., He, R., Hu, L., \& Liu, Y. (2013). Electricity consumption and human development level: A comparative analysis based on panel data for 50 countries. International Journal of Electrical Power \& Energy Systems, 53, 338-347. doi:10.1016/j.ijepes.2013.05.024

44. Ocal, O., \& Aslan, A. (2013). Renewable energy consumption-economic growth nexus in Turkey. Renewable and Sustainable Energy Reviews, 28, 494-499. doi:10.1016/j.rser.2013.08.036

45. Ouedraogo, N. S. (2013). Energy consumption and human development: Evidence from a panel cointegration and error correction model. Energy, 63, 28-41. doi:10.1016/j.energy.2013.09.067

46. Ozturk, I., \& Al-Mulali, U. (2015). Investigating the validity of the environmental Kuznets curve hypothesis in Cambodia. Ecological Indicators, 57, 324-330.

47. Pîrlogea, C. (2012). The Human Development Relies on Energy. Panel Data Evidence. Procedia Economics and Finance, 3, 496-501. 
doi:10.1016/s2212-5671(12)00186-4

48. Rafindadi, A. A., \& Ozturk, I. (2017). Impacts of renewable energy consumption on the German economic growth: Evidence from combined cointegration test. Renewable and Sustainable Energy Reviews, 75, 1130-1141. doi:10.1016/j.rser.2016.11.093

49. Sadorsky, P. (2009). Renewable energy consumption and income in emerging economies. Energy Policy, 37(10), 4021-4028. doi:10.1016/j.enpol.2009.05.003

50. Sarker, A.R., \& Alam, K. (2010). Nexus between Electricity Generation and Economic Growth in Bangladesh. Asian Social Science, ISSN 19112017, E-ISSN 1911-2025, Vol. 6, No. 12.

51. Sebri, M., \& Ben-Salha, O. (2014). On the causal dynamics between economic growth, renewable energy consumption, CO-2 emissions and trade openness: Fresh evidence from BRICS countries. Renewable and Sustainable Energy Reviews, 39, 14-23. doi:10.1016/j.rser.2014.07.033

52. Shahbaz, M., Raghutla, C., Chittedi, K. R., Jiao, Z., \& Vinh Vo, X. (2020). The Effect of Renewable Energy Consumption on Economic Growth: Evidence from the Renewable Energy Country Attractive Index. MPRA peper no. 101168. https://mpra.ub.uni-muenchen.de/101168/

53. Shahbaz, M., Loganathan, N., Zeshan, M., \& Zaman, K. (2015). Does renewable energy consumption add in economic growth? An application of auto-regressive distributed lag model in Pakistan. Renewable and Sustainable Energy Reviews, 44, 576-585. doi:10.1016/j.rser.2015.01.017

54. Shaari, M.S., Hussain, N.E., \& Ismail, M.S. (2012). Relationship between Energy Consumption and Economic Growth: Empirical Evidence for Malaysia. Business Systems Review, ISSN: 22803866, Volume 2 - Issue 1,

DOI: 10.7350/BSR.B02.2013

55. Sheikh, M. A. (2010). Energy and renewable energy scenario of Pakistan. Renewable and Sustainable Energy Reviews, 14(1), 354-363. doi:10.1016/j.rser.2009.07.037

56. Sinha, A., \& Sen, S. (2016). Atmospheric consequences of trade and human development: A case of BRIC countries. Atmospheric Pollution Research, 7(6), 980-989. doi:10.1016/j.apr.2016.06.003

57. Soava, G., Mehedintu, A., Sterpu, M., \& Raduteanu, M. (2018). Impact of Renewable Energy Consumption on Economic Growth: Evidence from European Union Countries. Technological and
Economic Development of Economy, 24(3), 914932. doi:10.3846/tede.2018.1426

58. Stewart, F., \& Ramirez, A. (2000). Economic Growth and Human Development. World Development Vol. 28, No. 2, pp. 197-219.

59. Tiwari, A. K. (2011). A structural VAR analysis of renewable energy consumption, real GDP and $\mathrm{CO} 2$ emissions: Evidence from India. Economics Bulletin, Vol. 31, no.2, pp. 1793-1806.

60. Tugcu, C. T., Ozturk, I., \& Aslan, A. (2012). Renewable and non-renewable energy consumption and economic growth relationship revisited: Evidence from G7 countries. Energy Economics, 34(6), 1942-1950. doi:10.1016/j.eneco.2012.08.021

61. UNDP (2020). Human Development Report 2019: Inequalities in Human Development in the 21st Century. Available at: http://www.hdr.undp.org/en/2019-report

62. Warr, B. S., \& Ayres, R. U. (2010). Evidence of causality between the quantity and quality of energy consumption and economic growth. Energy, 35(4), 1688-1693. doi:10.1016/j.energy.2009.12.017

63. Wang, Z., Danish, Zhang, B., \& Wang, B. (2018). Renewable energy consumption, economic growth and human development index in Pakistan: Evidence from simultaneous equation model. Journal of Cleaner Production, 184(2018), 10811090. https://doi.org/10.1016/j.jclepro.2018.02.260

64. World Bank (2020). Human Development Index Data of Bangladesh Human Development Indicators. Available at: http://www.hdr.undp.org/en/countries/profiles/BG $\mathrm{D}$

65. World Bank (2020). World development indicators. World Bank, Washington, DC. Available at: https://data.worldbank.org/indicator

66. Zaman, K., Ahmad, A., Hamzah, T. A. A. T., \& Yusoff, M. M. (2015). Environmental Factors Affecting Health Indicators in Sub-Saharan African Countries: Health is Wealth. Social Indicators Research, 129(1), 215-228. doi:10.1007/s11205015-1100-9 